\title{
Le stockage des céréales en milieu désertique : le ghird, dune garde-manger (Egypte)
}

Note de recherche

\section{Jacques Hivernel}

\section{OpenEdition}

\section{Journals}

Édition électronique

URL : https://journals.openedition.org/tc/491

DOI : $10.4000 /$ tc. 491

ISSN : 1952-420X

\section{Éditeur}

Éditions de l'EHESS

Édition imprimée

Date de publication : 1 octobre 1996

ISSN : 0248-6016

\section{Référence électronique}

Jacques Hivernel, « Le stockage des céréales en milieu désertique : le ghird, dune garde-manger

(Egypte) », Techniques \& Culture [En ligne], 27 | 1996, mis en ligne le 28 octobre 2005, consulté le 29 septembre 2022. URL : http://journals.openedition.org/tc/491 ; DOI : https://doi.org/10.4000/tc.491

Ce document a été généré automatiquement le 29 septembre 2022.

Tous droits réservés 
Le stockage des céréales en milieu désertique : le ghird, dune gardemanger (Egypte)

Note de recherche

Jacques Hivernel 